\title{
Efficacy of Curcumin Supplementation in Asthma: A Systematic Review and Meta-Analysis
}

\author{
Tabitha M. Grow \\ Portland State University \\ Adam Sadowski \\ National University of Natural Medicine
}

Follow this and additional works at: https://pdxscholar.library.pdx.edu/mcnair Let us know how access to this document benefits you.

\section{Recommended Citation}

Grow, Tabitha M. and Sadowski, Adam (2021) "Efficacy of Curcumin Supplementation in Asthma: A Systematic Review and Meta-Analysis," PSU McNair Scholars Online Journal: Vol. 15: Iss. 1, Article 3. https://doi.org/10.15760/mcnair.2021.15.1.3 
Title: Efficacy of Curcumin Supplementation in Asthma: A Systematic Review and MetaAnalysis

Authors: Tabitha Grow ${ }^{1}$, Adam Sadowski, ND, $\mathrm{MS}^{2}$

1. Portland State University, Portland, OR, USA

2. Helfgott Research Institute, National University of Natural Medicine, Portland, OR, USA

Corresponding Author: Tabitha Grow, email: growtab@pdx.edu 
Objective: Over 23 million people are affected by asthma in the United States and 262 million individuals globally. Asthma, if poorly controlled, is associated with significant morbidity as well as increased risk for mortality. Several complex inflammatory pathways and processes are involved leading to an increase in immune cell activation. Curcumin, the active constituent found in turmeric, has been studied in numerous in-vivo and in-vitro studies to generate antiinflammatory effects in pulmonary diseases. More recently, an increase in clinical data has become available, and since the most recent review assessing the role of curcumin in pulmonary disorders, additional clinical trials have been published. We provide the first meta-analysis evaluating the efficacy of curcumin supplementation in asthma.

Methods: We searched PubMed and Google Scholar for eligible studies up to June 30, 2021, using medical subject headings and keywords for asthma. Any clinical trial design, conducted in humans, assessing the efficacy of curcumin on asthma related symptoms and lung functioning were included. Two authors, using predefined criteria, independently screened, extracted data, and assessed risk of bias from included studies using predefined criteria. Random effects metaanalysis was performed for each outcome, with effect size reported as mean difference (MD) or as a standardized mean difference.

Results: 1,216 studies were screened, 8 included for review $(\mathrm{n}=509)$ and adequate data from 3 trials $(\mathrm{n}=203)$ included for meta-analysis. Most participants were of female sex $(52.2 \%)$ and the mean age (SD) of participants was 39.23 (14.7) years. The forced expiratory volume in one second (FEV1\%) improved with curcumin supplementation (3 studies; pooled MD = $3.70(1.00$, 
6.41), $\mathrm{p}=0.007, \mathrm{I}^{2}=0 \%$ ) compared to control. Efficacy of curcumin supplementation on asthma symptoms more generally were discordant and safety data was only reported in two trials.

Conclusions: Supplementation with curcumin may provide small improvements in FEV1\%, however conclusions are limited by the small number of studies and sample sizes, poor methodological quality, inconsistent reporting of asthma related outcomes and high risk of bias of included studies. Additional, high-quality, human trials are needed to assess the efficacy of curcumin supplementation more robustly in asthma. 


\section{Introduction:}

Asthma is a prevalent immune mediated disorder often associated with sensitivities to airborne environmental irritants. Globally, the World Health Organization (WHO) estimates 262 million people have asthma and an estimated 25 million individuals in the United States, according to The Center for Disease Control and Prevention (CDC). ${ }^{1,2}$ Asthma is more prevalent amongst females and direct and indirect costs result in an annual expenditure between $\$ 56$ to $\$ 82$ billion. $^{2-4}$

Asthma's pathophysiology is complex, involving several mechanistic pathways ultimately leading to the interaction of Nuclear Factor kappa-light-chain-enhancer of activated B-cells $(\mathrm{NF} \kappa \mathrm{B})$ cross-linking with IgE. This cross-linking activates mast cells, basophils and eosinophils causing a release of histamines and other inflammatory mediators such as c-reactive protein (CRP), tumor necrosis factor- $\alpha(\mathrm{TNF}-\alpha)$ and, interleukins. ${ }^{5-7}$ These inflammatory mediators result in the constriction of airways producing clinical symptoms of asthma such as wheezing, breathlessness and frequent nighttime awakenings due to coughing. ${ }^{5}$

The Global Initiative for Asthma (GINA) utilizes clinical symptoms in addition to spirometry testing to diagnose asthma and categorizes asthma by clinical phenotype with further subclassification based on severity (intermittent, mild, moderate, and severe). ${ }^{8}$ Suspicion for asthma can be confirmed by spirometry when the forced expiratory volume of air in one second (FEV1) is able to increase by at least $12 \%$ following the use of a short acting bronchodilating agent. ${ }^{8}$ The use of various bronchodilators, corticosteroids, anti-inflammatory, and/or biologic agents are routinely used as standard of care therapies for asthma, however, the use of complementary and integrative health $(\mathrm{CIH})$ practices for asthma are also highly prevalent. An estimated $58.5 \%$ of adults in the U.S. use CIH practices for asthma, and although 
data is sparse and varies by region, an estimated $27-76 \%$ of children with asthma also use some form of CIH. ${ }^{9,10}$ In U.S. based adults, herbal therapies comprised $21 \%$ of the natural products used for asthma, however, which herbal therapies are used specifically, is less certain. ${ }^{9}$

Curcuma longa (turmeric), a plant species native to tropical South Asia, has been traditionally used as a medicinal herb for centuries in Ayurvedic and Chinese medicine. ${ }^{5,11}$ Its rhizome is a common ingredient in many types of dishes such as curry, and $\mathrm{Ng}$ et al., suggested regular consumption of curry-based meals were independently associated with improvements in asthma after adjusting for gender, age, height, housing status, smoking, occupational exposure, asthma/COPD history, dietary, and other dietary supplemental intake. ${ }^{12}$ The main constituent of Curcuma longa, curcumin, has also routinely demonstrated anti-inflammatory effects in a variety of health-related conditions. ${ }^{11,13,14}$ Recently, there has been an increasing amount of literature available on the potential therapeutic role of curcumin for the treatment of pulmonary disorders including asthma, however, reviews of the literature are largely limited to investigating its effects from in-vivo or in-vitro models. . $^{5,11}$

Despite a recent 2017 comprehensive review assessing curcumin in pulmonary diseases, only two clinical trials assessing its role in asthma were included, provided conflicting results, and failed to include a 2010 randomized controlled trial. ${ }^{5,15}$ Given several clinical trials have been published since then, the purpose of this study is to systematically review the literature and provide the most up to date clinical evidence assessing the efficacy and safety of curcumin supplementation in asthmatics. To our knowledge, we are also the first authors to meta-analyze the effects of curcumin supplementation in asthma compared to controls. 


\section{Methods:}

This study followed the Preferred Reporting Items for Systematic Reviews and MetaAnalyses (PRISMA) guidelines. ${ }^{16}$ A protocol of this review was not prospectively registered.

\section{Eligibility for inclusion:}

\section{Patients:}

Review authors included all randomized controlled trials (RCTs) and quasi-RCTs assessing the efficacy of curcumin supplementation for asthma. Studies were included if asthma participants were diagnosed by a physician or met asthma diagnostic criteria by spirometry at study entry. Primary study authors were contacted by email for any missing or unclear information, however, studies were not excluded from narrative review if no response was obtained, given the limited number of publications available. Conference abstracts of clinical data was also included if sufficient data could be obtained. No restrictions were placed on age, sex, or weight of participants; type of asthma; setting; or language of publication provided a publication written in any language other than English could be sufficiently translated via Google Translate.

\section{Intervention:}

No restrictions were placed on curcumin supplementation administered in any form (capsule, powder, etc.) route (oral, parenteral, etc.), dose, or length of time. Given curcumin is the main active constituent of turmeric, studies utilizing turmeric in any form, route, dose, or length of treatment time were also included. 


\section{Comparison:}

Studies were eligible for inclusion if the intervention was compared to placebo, standard of care for asthma, or an active comparator.

\section{Outcomes:}

Studies were included if they measured at least one of the following outcome measures of interest: (1) asthma symptoms defined as the number of asthma exacerbations per week, nocturnal symptoms or awakenings due to asthma per week, frequency of rescue medication(s) used per week, number of daytime symptoms per week, and the total score on the Asthma Control Test (ACT) or Asthma Quality of Life Questionnaire (AQLQ); (2) lung functioning assessed by spirometry or peak flowmetry including the forced expiratory volume in one second $\left(\mathrm{FEV}_{1}\right)$, forced vital capacity $(\mathrm{FVC})$, ratio of $\mathrm{FEV}_{1}$ to $\mathrm{FVC}\left(\mathrm{FEV}_{1} / \mathrm{FVC}\right)$, or the peak expiratory flow rate (PEFR); and (3) safety and tolerability of curcumin supplementation.

\section{Exclusion criteria:}

Studies were excluded if they: (1). were conducted in animals; (2). were in-vitro, prospective or retrospective cohorts, cross-sectional, case-series, or case-control study designs; (3). unable to be translated via Google Translate; (4). included participants with other respiratory conditions (COPD, restrictive lung disease, pneumonia etc.); (5). did not report on any outcomes of interest as previously listed. 


\section{Search strategy:}

We searched PubMed and the first 1,000 results in Google Scholar from inception until June 2021 with the assistance of a university librarian trained in literature searches. Reference lists of included studies as well as previous reviews were hand searched. ClinicalTrials.gov and the International Clinical Trials Registry Platform Search Portal (ICTRP) were searched for ongoing or completed trials. The International Prospective Register of Systematic Reviews (PROSPERO) was searched for similar ongoing or recently completed systematic reviews addressing our study objectives. The search strategy can be accessed in the accompanying appendix at the end of the manuscript (appendix 1).

\section{Data Collection:}

Authors used Mendeley Desktop for literature search results and management of screening results. Studies meeting inclusion criteria were entered into Review Manager (RevMan) version 5.3 software to create risk of bias summaries, extract data from studies for

meta-analysis, and present results in forest plots if appropriate. ${ }^{17}$ Both authors screened titles and abstracts independently, with disagreements settled via consensus between study authors. TG and AS conducted all data extraction and data was inputted into RevMan5.3. Any disagreement in extraction of data was settled via consensus. Data items collected can be seen in table 1 .

\section{Risk of Bias Assessment:}

The Cochrane Collaboration's Risk of Bias tool was used to evaluate the risk of bias in seven selected domains included: 1) random sequence generation, 2) allocation concealment, 3) blinding of participants and personnel, 4) blinding of outcome assessment, 5) incomplete 
outcome data, 6) selective reporting, and 7) other biases. ${ }^{18}$ Each domain of bias was rated as low risk, unclear risk, or high risk of bias, respectively.

\section{Data Analysis:}

Due to the heterogeneity across study methodologies in addition to adequate data only available for assessing FEV1\%, a random-effects meta-analysis was used to derive pooled weighted mean differences (WMD) with $95 \%$ confidence intervals (95\% CI) using an inverse variance model of post-intervention effects. ${ }^{19}$ Heterogeneity across studies was calculated using the $\mathrm{I}^{2}$ statistic to assess heterogeneity between studies for study results. We considered an $\mathrm{I}^{2}$ of $0-24 \%$ as low heterogeneity, $25-49 \%$ as mild heterogeneity, $50-74 \%$ as high heterogeneity, and $\mathrm{I}^{2}>75 \%$ considered as extensive heterogeneity. ${ }^{20}$ Given the lack of available studies for metaanalysis, heterogeneity was not further explored by sensitivity analyses or sub-group analyses. Furthermore, evidence for potential publication bias was not attempted given the paucity of data available.

\section{Results:}

1,216 studies were identified through database and registry search strategy; 8 were eligible for inclusion in the systematic review with 3 providing adequate data for meta-analysis (Figure 1). Two studies were identified in ClinicalTrials.gov of which, one was published and identified in our PubMed search, with another study currently in progress (NCT04353310). Two additional ongoing studies were found in the ICTRP (IRCT20191221045837N3) and IRCT20161226031584N2). No relevant reviews were identified in PROSPERO. 


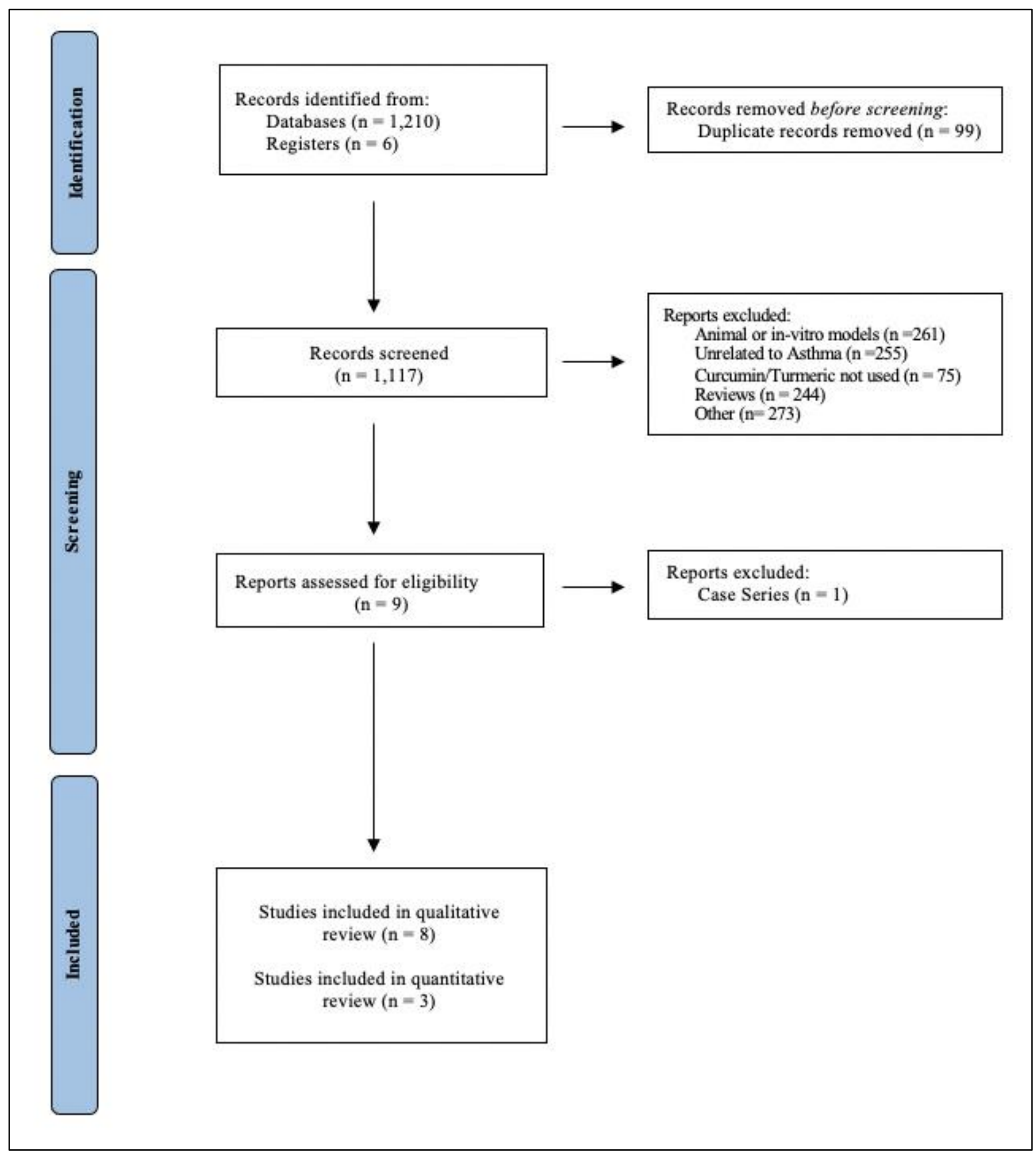

Figure 1: Preferred Reporting Items for Systematic Reviews and Meta-Analyses flow diagram. 


\section{Study characteristics:}

Study characteristics can be seen in Table 1. Two studies were conducted in Bosnia and Herzegovina, ${ }^{23,27}$ with one study each conducted in Egypt ${ }^{15}$, India $^{26}$ Indonesia $^{24}$, Iraq $^{21}$, Brazil $^{22}$, and the United States of America. ${ }^{25}$ Four studies compared curcumin to placebo ${ }^{15,22,25,27}$, five compared curcumin added to standard of care/active comparator vs standard of care/active comparator alone $21,23,24,26,27$, two compared combination products containing curcumin to placebo or control ${ }^{15,21}$, and one trial compared powdered whole turmeric to identical placebo. ${ }^{22}$ In one study, data was only available by conference abstract, however, despite attempts at contacting authors, further information was unable to be obtained. ${ }^{23}$ The longest trial length was six-months ${ }^{22}$, with the shortest trial performed by Sutedijo et al, however, the exact length of the study was unclear. ${ }^{24}$

\section{Participant characteristics:}

There was a total of $n=509$ participants across 8 studies $(n=203$ included in metaanalysis) with a total of $n=240$ in curcumin, $n=269$ in control groups. Mean age $(39.23 \pm 14.7)$ of participants was reported in six studies, and 52.2\% of study participants from six studies were female.

\section{Risk of Bias in individual studies:}

Summary of the risk of bias of included studies can be seen in Figure 2. One reference was judged as having unclear risk of bias as it was published as a conference abstract only, without an ability to contact abstract authors. ${ }^{23}$ Due to significant drop out after randomization, one study was assessed as having high risk of bias for incomplete outcome data, and another 
failed to report data on ACT scores, frequency of rescue inhaler use, or dose of inhaled corticosteroids. ${ }^{22,25}$

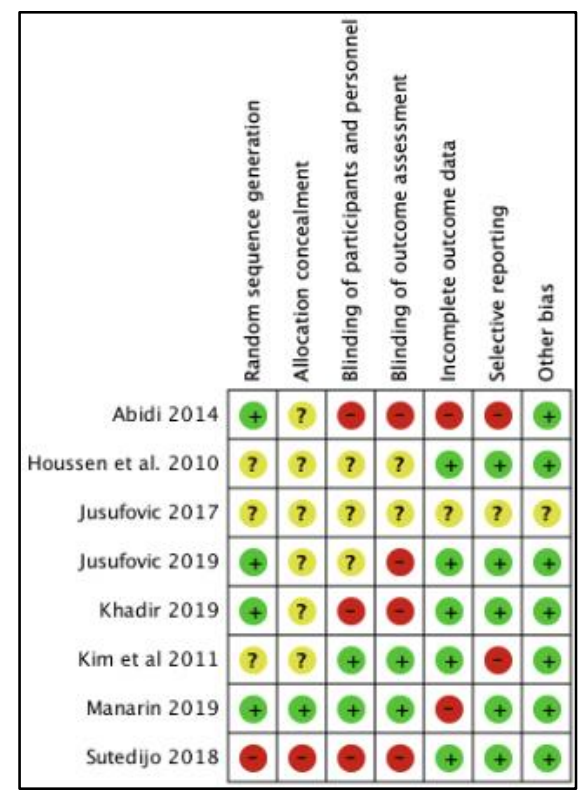

Figure 2: Risk of bias summary: review authors' judgements about each risk of bias item for each included study

\section{Effect of curcumin on lung functioning:}

Adequate data for meta-analysis was only available for FEV1\%, which improved with the addition of curcumin relative to control $\left(3\right.$ studies: $\mathrm{MD}=3.7 \%(1.0,6.4), \mathrm{P}=0.007, \mathrm{I}^{2}=$ 0\%). Data was available from one abstract, however, reported mean FEV1\% between groups were not incorporated into meta-analysis as it was unclear if standard deviations were reported despite efforts made in contacting corresponding authors. ${ }^{23}$ Manarin et al., reported FEV1\% graphically with medians and interquartile ranges, with no statistically significant difference between groups and was not incorporated into meta-analysis. ${ }^{22}$ Three studies $(n=115)$ reported FEV1 in liters however, heterogeneity in reporting FEV1 measures limited pooling results into meta-analysis. ${ }^{21,25,26}$ Of these three studies, two found no statistically significant difference between groups. ${ }^{21,25}$ 


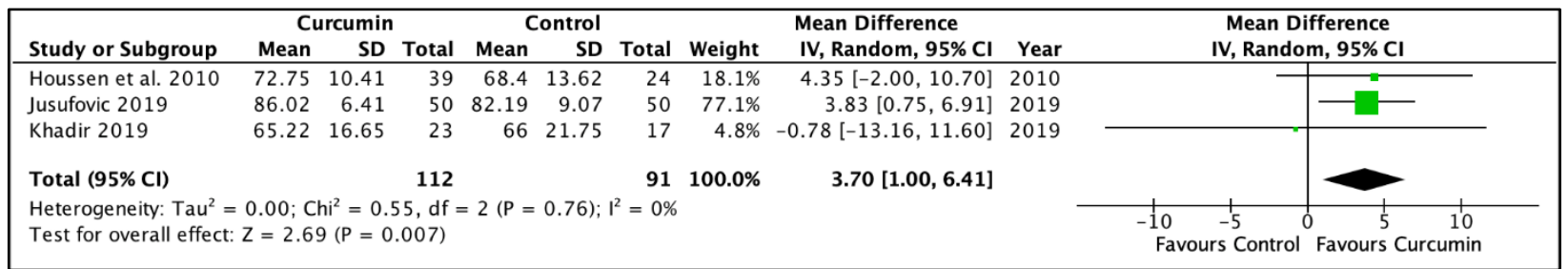

Figure 3: Forest plot for primary outcome comparing curcumin supplementation to controls. CI, confidence interval

Peak expiratory flow rate

Two studies $(\mathrm{n}=93)$ evaluated effects of curcumin supplementation on peak expiratory flow rate; one as a RCT and the other as a quasi-experimental study in hospitalized asthmatic patients. ${ }^{15,24}$ Neither study found statistically significant differences between groups.

\section{Effect of curcumin on asthma symptoms:}

A lack of adequate data was reported to assess the effects of curcumin on asthma symptoms and results are described narratively. Improvements in asthma symptoms are conflicting; four studies $(n=347)$ were able to identify statistically significant improvements in asthma symptoms compared to controls, ${ }^{15,22,23,27}$, with two studies $(\mathrm{n}=75)$ finding no statistically significant improvements in asthma symptoms. ${ }^{25,26}$ Asthma Control Test (ACT) scores were reported in two studies ${ }^{25,27}(\mathrm{n}=165)$ with conflicting results, and one abstract which found statistically significant improvements in the curcumin group compared to control. ${ }^{23}$

\section{Daytime symptoms}

Two studies $(n=123)$ reported the effects of curcumin supplementation for daytime symptoms with conflicting results. ${ }^{15,26}$ One study found a median of four fewer daytime 
symptoms per week compared to placebo group $(\mathrm{p}<0.001)^{15}$, however, another found no differences between curcumin or control groups in any symptom including difficulty breathing, wheezing, cough, or chest tightness. ${ }^{26}$

\section{Nocturnal symptoms}

Two studies $(\mathrm{n}=97)$ reported statistically significant reductions in nocturnal symptoms relative to control groups. ${ }^{15,22}$ Houssen et al., found a median reduction of two nocturnal awakenings per week compared to placebo $(\mathrm{p}<0.001),{ }^{15}$ with another study finding no statistically significant differences between groups in reductions of nighttime symptoms. ${ }^{26}$

\section{Need for rescue inhaler}

Two studies $(\mathrm{n}=97)$ reported statistically significant reductions in the need for rescue inhalers with the addition of curcumin relative to control ${ }^{15,22}$, with one able to demonstrate a median reduction of two fewer days per week of rescue inhaler use compared to placebo $(\mathrm{p}<0.001) .{ }^{15}$ In the trial by Manarain et al, at baseline, over $20 \%$ of participants in the curcumin group required daily use of rescue inhaler with none requiring daily rescue medication after sixmonths. ${ }^{22}$ At baseline, greater than $25 \%$ of control participants required daily use of rescue inhaler, and greater than $20 \%$ still required daily use of rescue inhaler at six-months. ${ }^{22}$ Two studies $(n=75)$ did not find any differences between groups in reliance on rescue inhalers, however, results were not readily available from one study despite attempts at contacting the authors. ${ }^{25,26}$

\section{Frequency of acute exacerbations}


The number of exacerbations per week was only recorded by one study which found a median reduction of two exacerbations per week relative to control group $(\mathrm{p}<0.001) .{ }^{15}$

\section{Safety of Curcumin:}

Only two trials $(n=94)$ reported safety data with neither study revealing increased risk of harm with curcumin..$^{22,26}$

\section{Discussion:}

Clinical data from eight studies $(\mathrm{n}=509)$ were included in this review, providing some evidence of an effect on lung functioning as seen by a $4 \%$ increase in FEV1, as well as overall improvements in asthma symptoms. These improvements build upon prior evidence highlighting curcumin's ability to inhibit inflammatory cytokines and upregulate anti-inflammatory immune activation leading to a reduction of airway hyperresponsiveness and relaxation of smooth muscle cells within the bronchopulmonary system..$^{5,7,28}$

Heterogeneity in how asthma symptoms were reported by included studies prevented pooling of results to provide a quantitative estimate for how much of an effect curcumin supplementation can provide for specific asthma related symptoms (e.g., daytime symptoms, nocturnal symptoms, reliance on rescue inhaler). Despite most studies suggesting improvements in asthma related symptoms, the overall methodological quality of included studies was low, with only two double blinded RCTs available, and most studies at unclear or high risk of bias. As such, readers should interpret our findings with caution and three additional on-going clinical trials (NCT04353310, IRCT20191221045837N3 and IRCT20161226031584N2) are likely to impact our findings after data become available. 


\section{Strengths:}

This is the first review the study authors are aware of that provides a meta-analysis of clinical data evaluating the effects of curcumin supplementation in asthma. We have included the largest number of studies conducted in humans with asthma compared to previously conducted

reviews which were limited to only two studies. ${ }^{5,11}$ Additional strengths include a comprehensive search strategy not limited to the English language and adherence to the PRISMA checklist. Limiting assessments of lung function, asthma symptoms, and safety of curcumin supplementation to randomized trials provided for more robust conclusions about the efficacy of curcumin supplementation.

\section{Limitations:}

Our review is limited by the number of studies available, small sample sizes of included studies, duration of follow up/length of treatment, inconsistencies in reporting of outcome measures, and risk of bias of included studies. Two studies additionally utilized mixed products and dosing strategies varied widely between $15 \mathrm{mg}-2,200 \mathrm{mg}$ across studies. ${ }^{15,21}$ Additionally, findings are further limited by a lack of sufficient data assessing the impact of curcumin supplementation across a spectrum of asthma severities.

\section{Implications/Recommendations for research:}

We recommend future investigations to report on all lung functioning measures available through spirometry and to report asthma symptoms in an identical and consistent manner utilizing standardized asthma symptom questionnaires such as the ACT or AQLQ with total and 
sub-scores readily available. Future studies should address concerns around the paucity of data available in children and adolescents as well as safety of curcumin supplementation. Although curcumin in doses as high as $12,000 \mathrm{mg}$ appear to be safe with no severe adverse effects, future studies should assess this in individuals being treated for asthma more specifically. ${ }^{29}$ Additionally, studies should utilize similar doses, dosing strategies, and formulations of curcumin, examine the impact of curcumin across asthma severities, and improve upon the methodological quality currently available.

Due to the hydrophobic and lipophilicity of curcumin, its bioavailability and absorption is notoriously low, known to degrade at physiological $\mathrm{pH}$ and rapidly metabolized, limiting its therapeutic effects. ${ }^{11,30}$ Chauhan et al., were able to demonstrate increased therapeutic efficacy, via intranasal administration in a murine model of asthma, finding a reduction in inflammatory signaling. ${ }^{31}$ However, additional research in humans is necessary to identify if intranasal applications provide any advantage over oral supplementation for individuals with asthma.

\section{Implications for clinical practice:}

Based on the results from our review, the use of curcumin to provide clinical benefit in asthma is likely minimal and recommending curcumin for asthma in clinical practice currently cannot be made and further high-quality research is necessary. Consistency in the reporting of lung functioning via spirometry as well as assessment of asthma symptoms are needed. It is still unclear at which dose/dosing strategy is most effective, how much benefit is provided to children or adolescents, if benefit is independent on asthma severity, and if benefits are sustained long term without significant adverse effects. If patients are utilizing curcumin supplementation with a perceived benefit, it is likely safe to continue supplementation as a dose escalation study of 
curcumin was reported to be safe at an observed dosage of $12,000 \mathrm{mg}$ in adults and adverse events were not associated with a dose dependent response. ${ }^{29}$

\section{Conclusions:}

This is the first systematic review with meta-analysis that study authors are aware of evaluating the efficacy of curcumin supplementation in humans with asthma. Limited evidence suggests short-term improvement in lung functioning assessed by spirometry with curcumin supplementation compared to control. Overall, asthma symptoms also seemed to improve, however, improvements in lung functioning and asthma symptoms need to be interpreted with caution due to the lack of adequate high-quality studies at low risk of bias. Recommendations for use in clinical practice cannot be made at this time and additional research with consistencies in outcome reporting, dosing, safety, length of follow up, and effects of curcumin supplementation in children and adolescents are warranted.

\section{Funding: None}

\section{References:}

1. World Health Organization. Asthma key facts. https://www.who.int/news-room/factsheets/detail/asthma Reviewed 2021. Accessed July 20, 2021

2. Centers for Disease Control and Prevention. Most recent national asthma data. https://www.cdc.gov/asthma/most_recent_national_asthma_data.htm. Reviewed March 30, 2021. Accessed July 20, 2021 
3. The Global Asthma Network. Global asthma report. http://globalasthmareport.org/Global\%20Asthma\%20Report\%202018.pdf Published 2018. Accessed July 21, 2021

4. Nurmagambetov T, Kuwahara R, Garbe P. The Economic Burden of Asthma in the United States, 2008-2013. Ann Am Thorac Soc. 2018;15(3):348-356.

5. Lelli D, Sahebkar A, Johnston TP, Pedone C. Curcumin use in pulmonary diseases: State of the art and future perspectives. Pharmacol Res. 2017;115:133-148.

6. Lloyd CM, Hawrylowicz CM. Regulatory T cells in asthma. Immunity. 2009;31(3):438449.

7. Zhu T, Chen Z, Chen G, et al. Curcumin Attenuates Asthmatic Airway Inflammation and Mucus Hypersecretion Involving a PPAR $\gamma$-Dependent NF- $\kappa$ B Signaling Pathway In Vivo and In Vitro. Mediators Inflamm. 2019;2019:1-15

8. 2020 Focused Updates to the Asthma Management Guidelines: A Report from the National Asthma Education and Prevention Program Coordinating Committee Expert Panel Working Group. J Allergy Clin Immunol 2020;146:1217-70

9. Kim EJ, Simonson J, Jacome S, Conigliaro J, Hanchate AD, Hajizadeh N. Disparities in complementary alternative medicine use and asthma exacerbation in the United States. $J$ Asthma. 2020;57(8):866-874.

10. Kalaci O, Giangioppo S, Leung G, et al. Complementary and alternative medicine use in children with asthma. Complement Ther Clin Pract. 2019;35:272-277.

11. Memarzia A, Khazdair MR, Behrouz S, et al. Experimental and clinical reports on antiinflammatory, antioxidant, and immunomodulatory effects of Curcuma longa and curcumin, an updated and comprehensive review. Biofactors. 2021;47(3):311-350. 
12. Ng TP, Niti M, Yap KB, Tan WC. Curcumins-rich curry diet and pulmonary function in Asian older adults. PLoS One. 2012;7(12):e51753

13. Hewlings SJ, Kalman DS. Curcumin: A Review of Its Effects on Human Health. Foods. 2017;6(10):92. doi:10.3390/foods6100092

14. Tabrizi R, Vakili S, Akbari M, et al. The effects of curcumin-containing supplements on biomarkers of inflammation and oxidative stress: A systematic review and meta-analysis of randomized controlled trials. Phytother Res. 2019;33(2):253-262.

15. Houssen ME, Ragab A, Mesbah A, et al. Natural anti-inflammatory products and leukotriene inhibitors as complementary therapy for bronchial asthma. Clin Biochem. 2010;43(10-11):887-890.

16. Liberati A, Altman DG, Tetzlaff J, et al. The PRISMA statement for reporting systematic reviews and meta-analyses of studies that evaluate healthcare interventions: Explanation and elaboration. BMJ 2009;339:b2700.

17. Review Manager (RevMan) [Computer program]. Version 5.3. The Nordic Cochrane Centre, The Cochrane Collaboration: Copenhagen,Denmark, 2014

18. Higgins JPT, Thomas J, Chandler J, et al (eds). Cochrane Handbook for Systematic Reviews of Interventions: Version 6.0. Cochrane: Chichester UK, 2019. (www.training.cochrane.org/handbook). Accessed June 2021.

19. DerSimonian R, Laird N. Meta-analysis in clinical trials revisited. Contemp Clin Trials 2015;45(pt A):139-45.

20. Higgins JP, Thompson SG, Deeks JJ, et al. Measuring inconsistency in meta-analyses. BMJ 2003;327(7414):557-60.

21. Khdair SA, Abdulridha MK, Shafek MAF. Effect of Curcumin Supplement on 
Pulmonary Functions, Total and Differential White Blood Cell Count, Serum Level of Leptin and Body Mass Index in a Sample of Iraqi Patients with Chronic Bronchial Asthma. Al Mustansiriyah J Pharm Sci. 2019;19(2):47-58.

22. Manarin G, Anderson D, Silva JME, et al. Curcuma longa L. ameliorates asthma control in children and adolescents: A randomized, double-blind, controlled trial. $J$ Ethnopharmacol. 2019;238:111882

23. Jusufovic E, Kosnik M, Jusufovic A, et al. Curcumin as an Add-on Therapy of Moderate Partially Controlled Asthma. European Respiratory Society; 2017: PA4695. doi:10.1183/1393003.congress-2017.pa4695

24. Sutedjo LA, Suradi S, Setijadi AR. The Effect of Curcumin On Plasma Histamine Level, PEF Variation and Length of Stay of Patients With Acute Exacerbation Asthma. $J$ Respirol Indones. 2018;38(2):100-108

25. Kim DH, Phillips JF, Lockey RF, Oral curcumin supplementation in patients with atopic asthma Allergy Rhinol. 2011;2(2):e51-e53

26. Abidi A, Gupta S, Agarwal M, Bhalla HL, Saluja M. Evaluation of Efficacy of Curcumin as an Add-on therapy in Patients of Bronchial Asthma. J Clin Diagn Res. 2014;8(8):HC19-HC24. doi:10.7860/JCDR/2014/9273.4705

27. Jusufovic E, Kosnik M, Arifhodzic N, et al. Curcumin improves step 4 asthma treatment: placebo-controlled, single blind study. Pulm Respir Med Int J. 2019. doi:10.30881/prmij.00010

28. Boskabady MH, Shakeri F, Naghdi F. Chapter 7 - The effects of Curcuma Longa L. and its constituents in respiratory disorders and molecular mechanisms of their action In: Atta-ur-Rahman, ed. Bioactive Natural Products. Vol 65. Studies in Natural Products 
Chemistry. Elsevier; 2020:239-269. Accessed July 2021.

doi:https://doi.org/10.1016/B978-0-12-817905-5.00007-X

29. Lao CD, Ruffin MT, Normolle D, et al. Dose escalation of a curcuminoid formulation. BMC Complement Altern Med. 2006;6(1):10

30. Anand P, Kunnumakkara AB, Newman RA, Aggarwal BB. Bioavailability of curcumin: problems and promises. Mol Pharm. 2007;4(6):807-818

31. Chauhan PS, Singh DK, Dash D, Singh R. Intranasal curcumin regulates chronic asthma in mice by modulating NF-кB activation and MAPK signaling. Phytomedicine. $2018 ; 51: 29-38$ 
Table 1: Characteristics of studies assessing efficacy of curcumin supplementation for asthma in clinical trials

\begin{tabular}{|c|c|c|c|c|c|c|c|c|c|}
\hline $\begin{array}{c}\text { Author, } \\
\text { Year }\end{array}$ & Location & Design & $\begin{array}{c}\text { Sample } \\
\text { size }\end{array}$ & $\begin{array}{c}\text { Sample } \\
\text { Characteristics }\end{array}$ & Duration & Intervention & Control & Outcome Measures & Results \\
\hline $\begin{array}{l}\text { Houssen } \\
\text { et al } \\
2010^{15}\end{array}$ & Egypt & RCT & $\mathrm{n}=63$ & $\begin{array}{l}\text { Non-smoking adults } \\
18-60 \text { years old, } \\
\text { with at last } 1 \text {-year of } \\
\text { chronic bronchial } \\
\text { asthma not } \\
\text { adequately } \\
\text { controlled with low } \\
\text { to moderate inhaled } \\
\text { corticosteroids }\end{array}$ & 4-weeks & $\begin{array}{l}\text { Combination } \\
\text { product taken } 3 \\
\text { times daily: } \\
150 \mathrm{mg} \\
\text { boswellic acid, } \\
50 \mathrm{mg} \text { licorice } \\
\text { extract, } 15 \mathrm{mg} \\
\text { curcumin }(\mathrm{n}=39)\end{array}$ & $\begin{array}{l}\text { Identical } \\
\text { placebo } \\
\text { capsule } \\
\text { (lactose) } \\
\text { taken } 3 \text { times } \\
\text { daily }(\mathrm{n}=24)\end{array}$ & $\begin{array}{l}\text { Daytime symptoms/wk; } \\
\text { nocturnal } \\
\text { symptoms/wk; } \\
\text { need for rescue } \\
\text { medication/wk; FVC\%; } \\
\text { FEV1\%; PEFR; } \\
\text { Frequency of acute } \\
\text { exacerbations per wk, } \\
\text { month, or year. }\end{array}$ & $\begin{array}{l}\text { Improvements in number of exacerbations/wk, } \\
\text { daytime and nighttime symptoms/wk, need for rescue } \\
\text { medication/wk, FVC. All p<0.001 compared to } \\
\text { placebo. } \\
\text { No statistically significant difference between groups } \\
\text { for FEV1\%, or PEFR. }\end{array}$ \\
\hline $\begin{array}{l}\text { Kim et al. } \\
2011^{25}\end{array}$ & USA & $\begin{array}{l}\text { Double Blind } \\
\text { RCT }\end{array}$ & $\mathrm{n}=15$ & $\begin{array}{l}\text { Adults } 18-60 \text { years } \\
\text { old with at least } 1- \\
\text { year of stable } \\
\text { persistent asthma, } \\
\text { FEV } 1 \geq 60 \% \text {, use of } \\
\text { low to moderate } \\
\text { inhaled } \\
\text { corticosteroids, and } \\
\text { allergic to dust } \\
\text { mites. }\end{array}$ & 3 months & $\begin{array}{l}\text { Curcumin } \\
1,000 \mathrm{mg} \text { twice } \\
\text { daily }(\mathrm{n}=9)\end{array}$ & Placebo $(n=6)$ & $\begin{array}{l}\text { Postbronchodilator } \\
\text { FEV1; ACT scores; } \\
\text { frequency of rescue } \\
\text { inhaler use; dose of } \\
\text { inhaled corticosteroids }\end{array}$ & $\begin{array}{l}\text { No statistically significant difference in any outcome } \\
\text { between groups }\end{array}$ \\
\hline $\begin{array}{l}\text { Abidi et } \\
\text { al. } 2014^{26}\end{array}$ & India & $\begin{array}{l}\text { Open label } \\
\text { RCT }\end{array}$ & $\mathrm{n}=60$ & $\begin{array}{l}\text { Non-smoking adults } \\
18-55 \text { years old } \\
\text { diagnosed with mild } \\
\text { to moderate } \\
\text { bronchial asthma } \\
\text { and improvements } \\
\text { in FEV1 } 15 \% \\
\text { after salbutamol } \\
\text { administration or } \\
\text { FEV1 between } 60 \text { - } \\
80 \% \text {. }\end{array}$ & 4-weeks & $\begin{array}{l}\text { Curcumin } \\
500 \mathrm{mg} \text { twice } \\
\text { daily added on } \\
\text { to standard of } \\
\text { care }(n=37)\end{array}$ & $\begin{array}{l}\text { Standard of } \\
\text { Care only } \\
(\mathrm{n}=40)\end{array}$ & $\begin{array}{l}\text { Asthma symptoms } \\
\text { (dyspnea, wheezing, } \\
\text { cough, chest tightness, } \\
\text { nocturnal symptoms, } \\
\text { total symptom score); } \\
\text { pre-bronchodilator } \\
\text { FEV1; post- } \\
\text { bronchodilator FEV1 }\end{array}$ & $\begin{array}{l}\text { No statistically significant difference between groups } \\
\text { in improvement of clinical symptoms. } \\
\text { Curcumin improved FEV1 measures compared to } \\
\text { placebo, all p<0.001. }\end{array}$ \\
\hline $\begin{array}{l}\text { Jusufovic } \\
\text { et al 2017 } \\
\text { (abstract) }{ }^{23}\end{array}$ & $\begin{array}{l}\text { Bosnia and } \\
\text { Herzegovina }\end{array}$ & N/A & $\mathrm{n}=100$ & $\begin{array}{l}\text { Non-smokers with } \\
\text { moderately } \\
\text { controlled asthma } \\
\text { on stable doses of } \\
\text { inhaled } \\
\text { glucocorticoids }\end{array}$ & 2 months & $\begin{array}{l}\text { Curcumin } \\
500 \mathrm{mg} \text { twice } \\
\text { daily added to } \\
\text { inhaled } \\
\text { glucocorticoid } \\
\text { therapy }(\mathrm{n}=50)\end{array}$ & $\begin{array}{l}\text { Inhaled } \\
\text { glucocorticoid } \\
(\mathrm{n}=50)\end{array}$ & FEV1\%, ACT, AQLQ & $\begin{array}{l}\text { Curcumin improved FEV1\% }(\mathrm{p}<0.001) \text {, } \\
\text { ACT }(\mathrm{p}<0.001) \text {, and AQLQ }(\mathrm{p}=0.014) \text { scores }\end{array}$ \\
\hline $\begin{array}{l}\text { Sutedijo et } \\
\text { al } 2018^{24}\end{array}$ & Indonesia & $\begin{array}{l}\text { Quasi- } \\
\text { experimental } \\
\text { study }\end{array}$ & $\mathrm{n}=30$ & $\begin{array}{l}\text { Non-smokers, at } \\
\text { least } 18 \text { years old } \\
\text { diagnosed with an } \\
\text { acute asthma } \\
\text { exacerbation } \\
\text { requiring } \\
\text { hospitalization }\end{array}$ & N/A & $\begin{array}{l}\text { Curcumin } \\
550 \mathrm{mg} \text { four } \\
\text { times daily } \\
\text { added to } \\
\text { standard of care } \\
(\mathrm{n}=15)\end{array}$ & $\begin{array}{l}\text { Standard of } \\
\text { care only } \\
(\mathrm{n}=15)\end{array}$ & $\begin{array}{l}\text { PEFR; length of } \\
\text { hospital stay }\end{array}$ & $\begin{array}{l}\text { No statistically significant differences between groups } \\
\text { in PEF improvement, or length of hospital stay. }\end{array}$ \\
\hline
\end{tabular}

FEV1: Forced Expiratory Volume in 1 second; FEV1\%: Predicted Forced Expiratory Volume in 1 second; FVC: Forced Vital Capacity; PEFR: Peak Expiratory Flow Rate; ACT:

Asthma Control Test; AQLQ: Asthma Quality of Life Questionnaire; wk: week 
Table 1 Continued

\begin{tabular}{|c|c|c|c|c|c|c|c|c|c|}
\hline $\begin{array}{l}\text { Author, } \\
\text { Year }\end{array}$ & Location & Design & $\begin{array}{l}\text { Sample } \\
\text { size }\end{array}$ & $\begin{array}{l}\text { Sample } \\
\text { Characteristics }\end{array}$ & Duration & Intervention & Control & Outcome Measures & Results \\
\hline $\begin{array}{l}\text { Jusufovic } \\
\text { et al } \\
2019^{27}\end{array}$ & $\begin{array}{l}\text { Bosnia and } \\
\text { Herzegovina }\end{array}$ & $\begin{array}{l}\text { Single blind } \\
\text { RCT }\end{array}$ & $\mathrm{n}=150$ & $\begin{array}{l}\text { Non-smoking adults } \\
\text { at least } 18 \text { years old } \\
\text { with moderate to } \\
\text { severe asthma } \\
\text { requiring moderate } \\
\text { doses of inhaled } \\
\text { glucocorticoids. }\end{array}$ & 3 months & $\begin{array}{l}\text { Curcumin } 500 \mathrm{mg} \\
\text { twice daily added to } \\
\text { inhaled glucocorticoid } \\
\text { therapy }(\mathrm{n}=50)\end{array}$ & $\begin{array}{l}\text { Placebo } \\
\text { added to } \\
\text { inhaled } \\
\text { glucocorticoid } \\
\text { therapy } \\
(\mathrm{n}=50) \\
\text { Inhaled } \\
\text { glucocorticoid } \\
\text { group alone } \\
(\mathrm{n}=50)\end{array}$ & FEV1\%, ACT, AQLQ & $\begin{array}{l}\text { FEV1\%, ACT and AQLQ improved in all groups. } \\
\text { Statistically significant improvements in FEV1\%, } \\
\text { ACT, and AQLQ with curcumin compared to both } \\
\text { placebo and control group. }\end{array}$ \\
\hline $\begin{array}{l}\text { Khadir } \\
2019^{21}\end{array}$ & Iraq & $\begin{array}{l}\text { Open-Label } \\
\text { RCT }\end{array}$ & $\mathrm{n}=40$ & $\begin{array}{l}\text { Chronic bronchial } \\
\text { asthma }\end{array}$ & 2 months & $\begin{array}{l}\text { Curcumin } 750 \mathrm{mg}+ \\
\text { Piperine } 5 \mathrm{mg} \text { twice } \\
\text { daily added to } \\
\text { standard of care }(\mathrm{n}= \\
\text { 23) }\end{array}$ & $\begin{array}{l}\text { Standard of } \\
\text { care only }(\mathrm{n}= \\
17)\end{array}$ & $\begin{array}{l}\text { FEV1\%; FEV1; } \\
\text { FEV1/FVC }\end{array}$ & $\begin{array}{l}\text { No statistically significant differences between } \\
\text { groups for FEV1\%, FEV1, or FEV1/FVC }\end{array}$ \\
\hline $\begin{array}{c}\text { Manarin } \\
2019^{22}\end{array}$ & Brazil & $\begin{array}{l}\text { Double Blind } \\
\text { RCT }\end{array}$ & $\mathrm{n}=34$ & $\begin{array}{l}\text { Children and } \\
\text { adolescents between } \\
7-18 \text { years of age } \\
\text { with persistent } \\
\text { asthma }\end{array}$ & 6 months & $\begin{array}{l}\text { Powdered Curcuma } \\
\text { longa } 30 \mathrm{mg} / \mathrm{kg} / \mathrm{day}\end{array}$ & $\begin{array}{l}\text { Identical } \\
\text { placebo } \\
\text { (maltodextrin) }\end{array}$ & $\begin{array}{l}\text { Frequency of } \\
\text { respiratory symptoms; } \\
\text { nighttime awakenings; } \\
\text { use of rescue inhaler; } \\
\text { interference with } \\
\text { normal activity; FEV1 }\end{array}$ & $\begin{array}{l}\text { No difference between groups in frequency of } \\
\text { symptoms, FEV1, or interference with normal } \\
\text { activity. Curcumin improved frequency of } \\
\text { nighttime awakenings }(p<0.001) \text {, decreased } \\
\text { frequency in use of rescue inhaler }(p<0.0001) \text {, and } \\
\text { overall disease control }(p<0.01) \text {. }\end{array}$ \\
\hline
\end{tabular}

FEV1/FVC: FEV1 to FVC ratio 


\section{Appendix 1: Search strategy}

\section{PubMed:}

1. Asthma $[\mathrm{MeSH}]$

2. Asthma* [tw]

3. Respiratory hypersensitivity $[\mathrm{MeSH}]$

4. Wheez* $[\mathrm{tw}]$

5. airway responsiveness [tw]

6. airway hyperreactivity [tw]

7. airway hyper-reactivity [tw]

8. Airway hyper-responsiveness [tw]

9. Bronchospasm [tw]

10. bronchial responsiveness [tw]

11. bronchial disorder [tw]

12. bronchial hyperreactivity [tw]

13. bronchial hyper-reactivity [tw]

14. lung function [tw]

15. ventilatory function [tw]

16. Pulmonary function [tw]

17. Respiratory function tests $[\mathrm{MeSH}]$

18. FEV [tw]

19. FEF $[\mathrm{tw}]$

20. FVC [tw]

21. PEF [tw]

22. PTF [tw]

23. Interluekin-4 [tw]

24. Interleukin-5 [MeSH]

25. IL-5 [tw]

26. IL5 [tw]

27. Interleukin-13 [MeSH]

28. IL-13 [tw]

29. IL13 [tw] 
30. \#1 OR \#2 OR \#3 OR \#4 OR \#5 OR \#6 OR \#7 OR \#8 OR \#9 OR \#10 OR \#11 OR \#12 OR \#13 OR \#14 OR \#15 OR \#16 OR \#17 OR \#18 OR \#19 OR \#20 OR \#21 OR \#22 OR \#23 OR \#24 OR \#25 OR \#26 OR \#27 OR \#28 OR \#29

31. Curcuma [MeSH]

32. Curcumin $[\mathrm{MeSH}]$

33. Turmeric [tw]

34. Tumeric $[\mathrm{tw}]$

35. Tetrahydrocurcumin [tw]

36. Curcum* [tw]

37. \#31 OR \#32 OR \#33 OR \#34 OR \#35 OR \#36

38. \#30 AND \#37

\section{Google Scholar:}

All words: Curcuma and Asthma

At least one word: Turmeric OR Curcuma OR Curcumin OR Lung Function OR Respiratory Hypersensitivity

\section{Appendix 2: PRISMA checklist:}




\begin{tabular}{|c|c|c|c|}
\hline Section/topic & $\#$ & Checklist item & $\begin{array}{l}\text { Reported on } \\
\text { page \# }\end{array}$ \\
\hline \multicolumn{4}{|l|}{ TITLE } \\
\hline \multicolumn{4}{|l|}{ ABSTRACT } \\
\hline Structured summary & 2 & $\begin{array}{l}\text { Provide a structured summary including, as applicable: background; objectives; data sources; study eligibility criteria, participants, and } \\
\text { interventions; study appraisal and synthesis methods; results; limitations; conclusions and implications of key findings; systematic } \\
\text { review registration number. }\end{array}$ & 2 \\
\hline \multicolumn{4}{|l|}{ INTRODUCTION } \\
\hline Rationale & 3 & Describe the rationale for the review in the context of what is already known. & 4 \\
\hline Objectives & 4 & $\begin{array}{l}\text { Provide an explicit statement of questions being addressed with reference to participants, interventions, comparisons, outcomes, and } \\
\text { study design (PICOS). }\end{array}$ & 5 \\
\hline \multicolumn{4}{|l|}{ METHODS } \\
\hline Protocol and registration & 5 & $\begin{array}{l}\text { Indicate if a review protocol exists, if and where it can be accessed (e.g., Web address), and, if available, provide registration } \\
\text { information including registration number. }\end{array}$ & 6 \\
\hline Eligibility criteria & 6 & $\begin{array}{l}\text { Specify study characteristics (e.g., PICOS, length of follow-up) and report characteristics (e.g., years considered, language, publication } \\
\text { status) used as criteria for eligibility, giving rationale. }\end{array}$ & $6-7$ \\
\hline Information sources & 7 & $\begin{array}{l}\text { Describe all information sources (e.g., databases with dates of coverage, contact with study authors to identify additional studies) in the } \\
\text { search and date last searched. }\end{array}$ & 8 \\
\hline Search & 8 & Present full electronic search strategy for at least one database, including any limits used, such that it could be repeated. & $\begin{array}{l}\text { Figure 1, } \\
\text { Appendix } 1\end{array}$ \\
\hline Study selection & 9 & $\begin{array}{l}\text { State the process for selecting studies (i.e., screening, eligibility, included in systematic review, and, if applicable, included in the meta- } \\
\text { analysis). }\end{array}$ & $\begin{array}{l}\text { Figure 1, } \\
\quad 8\end{array}$ \\
\hline Data collection process & 10 & $\begin{array}{l}\text { Describe method of data extraction from reports (e.g., piloted forms, independently, in duplicate) and any processes for obtaining and } \\
\text { confirming data from investigators. }\end{array}$ & 8 \\
\hline Data items & 11 & List and define all variables for which data were sought (e.g., PICOS, funding sources) and any assumptions and simplifications made. & $6-7$ \\
\hline Risk of bias in individual studies & 12 & $\begin{array}{l}\text { Describe methods used for assessing risk of bias of individual studies (including specification of whether this was done at the study or } \\
\text { outcome level), and how this information is to be used in any data synthesis. }\end{array}$ & 12 \\
\hline
\end{tabular}




\begin{tabular}{|c|c|c|c|}
\hline Section/topic & $\#$ & Checklist item & $\begin{array}{l}\text { Reported } \\
\text { on page \# }\end{array}$ \\
\hline Risk of bias across studies & 15 & $\begin{array}{l}\text { Specify any assessment of risk of bias that may affect the cumulative evidence (e.g., publication bias, selective reporting } \\
\text { within studies). }\end{array}$ & 12 \\
\hline Additional analyses & 16 & $\begin{array}{l}\text { Describe methods of additional analyses (e.g., sensitivity or subgroup analyses, meta-regression), if done, indicating which } \\
\text { were pre-specified. }\end{array}$ & $8-9$ \\
\hline \multicolumn{4}{|l|}{ RESULTS } \\
\hline Study selection & 17 & $\begin{array}{l}\text { Give numbers of studies screened, assessed for eligibility, and included in the review, with reasons for exclusions at each } \\
\text { stage, ideally with a flow diagram. }\end{array}$ & Figure 1 \\
\hline Study characteristics & 18 & $\begin{array}{l}\text { For each study, present characteristics for which data were extracted (e.g., study size, PICOS, follow-up period) and } \\
\text { provide the citations. }\end{array}$ & 11 \\
\hline Risk of bias within studies & 19 & Present data on risk of bias of each study and, if available, any outcome level assessment (see item 12). & Figure 2 \\
\hline Results of individual studies & 20 & $\begin{array}{l}\text { For all outcomes considered (benefits or harms), present, for each study: (a) simple summary data for each intervention } \\
\text { group (b) effect estimates and confidence intervals, ideally with a forest plot. }\end{array}$ & Figure 3 \\
\hline Synthesis of results & 21 & Present results of each meta-analysis done, including confidence intervals and measures of consistency. & $\begin{array}{c}\text { Figure } 3 \\
12-13\end{array}$ \\
\hline Risk of bias across studies & 22 & Present results of any assessment of risk of bias across studies (see Item 15). & $\begin{array}{l}\text { Figure } 2 \\
\quad 12\end{array}$ \\
\hline Additional analysis & 23 & Give results of additional analyses, if done (e.g., sensitivity or subgroup analyses, meta-regression [see Item 16]). & N/A \\
\hline \multicolumn{4}{|l|}{ DISCUSSION } \\
\hline Summary of evidence & 24 & $\begin{array}{l}\text { Summarize the main findings including the strength of evidence for each main outcome; consider their relevance to key } \\
\text { groups (e.g., healthcare providers, users, and policy makers). }\end{array}$ & $15-16$ \\
\hline Limitations & 25 & $\begin{array}{l}\text { Discuss limitations at study and outcome level (e.g., risk of bias), and at review-level (e.g., incomplete retrieval of } \\
\text { identified research, reporting bias). }\end{array}$ & $16-17$ \\
\hline Conclusions & 26 & Provide a general interpretation of the results in the context of other evidence, and implications for future research. & 18 \\
\hline \multicolumn{4}{|l|}{ FUNDING } \\
\hline Funding & 27 & $\begin{array}{l}\text { Describe sources of funding for the systematic review and other support (e.g., supply of data); role of funders for the } \\
\text { systematic review. }\end{array}$ & 19 \\
\hline
\end{tabular}

